\title{
СТИЛИСТИКА МЕДИАТЕКСТА
}

\author{
УДК $81^{\prime} 42$
}

\section{Завоевание аудитории в медиально опосредованной стратегической коммуникации (на примере польского информационного сервиса «Wiadomości»)}

\author{
Д. Кэмпа-Фигура \\ Университет Марии Кюри-Склодовской в Люблине, \\ Польша, 20-080, Люблин, Литовская площадь, 3
}

Для цитирования: Кэмпа-Фигура, Д. (2019). Завоевание аудитории в медиально опосредованной стратегической коммуникации (на примере польского информационного сервиса «Wiadomości»). Медиалингвистика, 6 (4), 496-511. https://doi.org/10.21638/spbu22.2019.406

Анализируется один из выпусков новостей информационного сервиса польского общественного телевидения Wiadomości, трактуемого как средство реализации информационной политики диспонента медиа, т. е. политики власти. Внимание акцентируется на наиболее выразительном лингвистическом механизме стратегической коммуникации - оценке. Описание оценки как механизма, способствующего завоеванию аудитории, позволило выявить ценности, к которым обращается правительство Республики Польша в процессе создания нарратива, формирующего его имидж. К этим ценностям относятся «успех» и «патриотизм», ставшие основой для распространения нарратива о власти как субъекте, имеющем патриотические мотивы. Механизм завоевания аудитории реализуется в двух планах функционирования текста - в плане содержания и в плане выражения. В случае с выбранным объектом исследования, говоря о плане содержания, необходимо обратить внимание на выбор тем, обсуждаемых в анализируемой информационной программе, их характеристики и причины, по которым эти темы были затронуты. В то же время, говоря о плане выражения, следует иметь в виду использование приемов, направленных на принятие адресатом определенного нарратива о Польше (а именно об актуальной польской власти), особенно использование разных способов оценивания действительности, являющейся предметом речи. Кроме того, обращается внимание на отношения между понятиями стратегическая коммуникация, public relations и пропаганда. Можно полагать, что современная стратегическая коммуникация функционирует наподобие public relations - в нее включена перспектива отправителя, вовлеченного в действия, названные этим словосочетанием. По сути нейтральные и даже положительные, StratCom и PR могут использоваться для определения действий, оцениваемых внешними субъектами как отрицательные.

() Санкт-Петербургский государственный университет, 2019 
Вместе с тем, характеризуя отношения между понятиями стратегическая коммуникаиия и связи с общественностью, необходимо обратить внимание на заключающееся в них доминирование позитивного мировосприятия, которое является основой одной из разновидностей пропаганды - пропаганды успеха.

Ключевые слова: стратегическая коммуникация, оценка, пропаганда, PR, нарратив.

Постановка проблемы. Понятие стратегической коммуникации в наши дни не ограничивается военной сферой ${ }^{1}$. Оно используется также для определения систематических и организованных коммуникативных действий, реализуемых публичными вещателями в публичном пространстве. Среди свойств понимаемой таким образом стратегической коммуникации можно отметить, в частности, характер отправителя, цель коммуникации и способы достижения этой цели.

Говоря об инициаторе стратегической коммуникации, необходимо помнить о его институциональном характере и, что самое важное, о принятой им точке зрения, которая основывается на проправительственности, лояльности, объективации субъективных ценностей отправителя, позитивном мировосприятии. Цель стратегической коммуникации - создание соответствующего имиджа отправителя, получение от аудитории поддержки, а также формирование соответствующего потребностям адресанта мировосприятия. Это означает, что основной целью StratCom является завоевание аудитории для принятия навязываемого мировоззрения и желаемого имиджа отправителя. Эта цель реализуется с помощью публичной дипломатии и интересующей нас медиально опосредованной коммуникационной деятельности ${ }^{2}$.

В статье прежде всего хотелось бы обратить внимание на выбранные механизмы завоевания аудитории в рамках медиально опосредованной стратегической коммуникации. Поскольку реализация этой цели связана с необходимостью анализа одного из направлений StratCom, в результате проведенного анализа можно будет обозначить ценности, к которым обращается отправитель стратегической коммуникации, и выделить основывающиеся на них нарративы.

Надеемся, что проведенное исследование и литература, посвященная проблемам стратегической коммуникации, позволят сформулировать выводы относительно отношения категории StratCom с понятиями $P R$ и пропаганда.

Стратегическая коммуникация как военная и невоенная проблема. Понятие стратегической коммуникации появилось как термин военных информационных операций (действий), осуществляемых вооруженными силами многих государств с начала XXI в. Как пишет Томаш Кацала, возникновение этого понятия является показателем роста значимости процессов социального общения, происходящих в динамично развивающейся информационной среде [Кacała 2010: 350]. Истоки военно обусловленной стратегической коммуникации можно обнаружить во время

${ }^{1} \mathrm{~B}$ описании стратегической коммуникации будет использоваться не только полное название этого коммуникативного действия, но и общепринятое сокращение StratCom.

${ }^{2}$ Как пишет Томаш Кацала, «американский Департамент обороны в 2004 году причислил к стратегической коммуникации следующие элементы: информационные операции (Information Operations), публичную дипломатию (Public Diplomacy), международные вещательные услуги (International Broadcasting Services), печатно-информационную деятельность (Public Affairs)» [Kacała 2012: 18]. 
первой войны в Персидском заливе, которая впервые была названа информационной, однако само понятие было сформулировано только в начале XXI в. [Касаła 2015: 147].

Как отмечает Т. Кацала, способ понимания стратегической коммуникации зависит от первичной категоризации этого понятия как информационных операций (действий) - терминологического определения, использующегося в области военной деятельности. Эти информационные действия определяются Департаментом обороны США следующим образом: «Information operations (IO) are described as the integrated employment of electronic warfare (EW), computer network operations (CNO), psychological operations (PSYOP), military deception (MILDEC), and operations security (OPSEC), in concert with specified supporting and related capabilities, to influence, disrupt, corrupt, or usurp adversarial human and automated decision making while protecting our own ${ }^{3}$ [Information Operations 2006: ix].

В то же время в правилах поведения польских сухопутных войск под инбормаицинными действиями принято понимать «предприятия, цель которых - влияние на восприятие (мнение) и отношение отдельных индивидов и групп, которое приводит к выгодному с собственной точки зрения поведению. Это предприятия, имеющие влияние на принятие политических и военных решений путем воздействия на информацию, основные информационные процессы и системы командования, управления, связи и программного обеспечения противника, а также защищающие собственную информацию, информационные процессы и системы» [Regulamin... 2008: 325].

Обращение к способу понимания словосочетания инбормационные действия позволяет воспроизвести мотивы, лежащие в основе процесса номинации, результатом которого было создание стратегической коммуникации, и определить отношения между StratCom, PR и пропагандой (предложение характеристики отношения между этими понятиями представлено в последнем параграфе статьи).

Милитаристское понимание информационных действий приводит к способу дефинирования стратегической коммуникаици. Как пишет Т. Кацала, одно из первых определений Strategic Communication (StratCom) было сформулировано по требованию «Многонационального эксперимента 6» (Multinational Experiment 6). Стратегическая коммуникация понимается как «функция, интегрирующая коалиционные информационные усилия для защиты жизненно важных интересов и достижения целей, а также продвижения сплоченности коалиции» 4 .

Западный способ понимания StratCom стал образцом для его польской дефиниции. В публикации Koncepcja komunikacji strategicznej w Siłach Zbrojnych RP («Концепция стратегической коммуникации в Вооруженных силах Республики Польша»)

\footnotetext{
${ }^{3}$ Информационные операции (IO) описываются как комплексное использование средств радиоэлектронной борьбы (EW), компьютерных сетевых операций (КСО), психологических операций (PSYOP), мероприятий по оперативной маскировке (MILDEC) и операций по обеспечению безопасности (OPSEC) в сочетании с определенными поддерживающими и связанными возможностями для воздействия, препятствия, подкупа или узурпации человеческих и автоматизированных решений с целью защиты наших собственных интересов.

${ }^{4}$ В статье приводится сделанный Томашем Кацалой [Kacała 2012] перевод определения стратегической коммуникации, данного в документе «Strategic Communication in Multinational Coalition Operations Within a Comprehensive Approach. Working draft, Version 1.0, Strausberg, 30 November 2009».
} 
это понятие объясняется как «целенаправленные действия организационных ячеек и подразделений SZRP (RON), которые охватывают производство и распространение определенного сообщения, направленного на внутреннюю среду, внешнее окружение (в том числе оппонентов), и координируются системно с кинетическими действиями. Способности, интегрированные и развивающиеся в рамках стратегической коммуникации, включают в себя деятельность военной пресс-службы, рекламную деятельность, информационные операции, психологические операции, CIMIC, KLE и социальные сети» 5 .

Так понимаемая StratCom является сегодня важной военной проблемой, обсуждение которой направлено на практическое применение указаний относительно функционирования этой коммуникации [Zgryziewicz 2018].

Первое вневоенное использование выражения стратегическая коммуникация восходит к научным рассуждениям, посвященным проблеме социальной безопасности, центральная категория которой - понятие инбормационной войны. Затем StratCom присваивается специалистами, занимающимися маркетинговой коммуникацией и связями с общественностью. Констатация сходства действий, названных стратегической коммуникацией, и действий в рамках $\mathrm{PR}$ привела, с одной стороны, к взаимозаменяемости этих терминов ${ }^{6}$, с другой стороны, к попыткам разграничения понятий ${ }^{7}$. Для нашего исследования важно, что в связи с оперативной позицией медиа как носителя стратегической коммуникации понятие StratCom появилось также в научных рефлексиях, посвященных медиакоммуникации и журналистике. Попытку включения термина стратегическая коммуникация в область интересов польской медиалогии предприняли Агнешка Шиманьска и Марек Яхимовский [Szymańska 2014; Jachimowski 2016]. В связи с обозначенными выше границами нашего исследования стоит подробнее остановиться только на второй статье, посвященной внутренней стратегической коммуникации государства. М. Яхимовский занялся взаимодействием СМИ с формами периодической коммуникации и диспонентами медиа. Признав, что основной миссией периодической медиакоммуникации является информационная коммуникация, он констатировал, однако, использование этой коммуникации «посредством разных видов персуазивной коммуникации» [Jachimowski 2016: 14]. Стратегическую (а также маркетинговую)

${ }^{5}$ Определение стратегической коммуникации, взятое из «Концепции...», приводит польский исследователь Збигнев Моджеевский [Modrzejewski 2014].

${ }^{6}$ Примером использования понятия стратегической коммуникации в рефлексии на тему бренда является книга Магдалены Лукасюк «PR NGOsów. Komunikacja strategiczna organizacji pozarządowych» [Łukasiuk 2014].

7 Интересна с точки зрения разграничения понятий StratCom и PR статья «Komunikacja strategiczna w naukach o zarządzaniu i jakości oraz w naukach o bezpieczeństwie» [Nowicka, Załoga, Ciekanowski 2018]. Авторы, продемонстрировав сходство механизмов StratCom и PR, признали, что «непосредственная аналогия в этом случае кажется необоснованной и нецелесообразной, хотя бы из-за разного предмета интереса и обусловленности функционирования маркетинговой и стратегической коммуникации», и хотя «отождествление обоих терминов может появиться в тех странах, которые с учетом успешной экономики развивали инструменты public relations в отношении формирования имиджа государства посредством силы национального бренда экономических продуктов <..>, несмотря на строительный материал, которым является понятие стратегии, совершение прямых интердисциплинарных заимствований видится нежелательным» [Nowicka, Załoga, Ciekanowski 2018: 201]. Авторы при этом отметили, что «сами уровни функционирования организаций (стратегический, операционный и тактический) в науках об управлении и качестве, а также в науках о безопасности не совпадают» [Nowicka, Załoga, Ciekanowski 2018: 202]. 
коммуникацию Яхимовский включил в область персуазивной коммуникации, служащей (по его мнению) «мистифицирующему познанию и событийному правдоподобию... убеждени(ю), а не информировани(ю) или объективизаци(и)» [Jachimowski 2016: 14].

«В персуазивной коммуникации реализаторы сообщений (в рекламе, связях с общественностью или пропаганде) руководствуются прежде всего интересами заказчика. Адресат такого контента рассматривается как предмет воздействия пассивный получатель или потребитель средств массовой информации. Транслируемые сообщения имеют характер публикаций, представляющих точку зрения диспонента медиа и его клиентов (например, рекламодателей)... Переданные сообщения имеют... персуазивные задачи, влияющие на отношение и поведение целевых групп, для которых они предназначены. Эффектом этого действия должны быть увеличение продаж рекламируемого продукта, узнаваемость бренда, положительный/отрицательный имидж политика или организации» [Jachimowski 2016: 14]. «Многие организации в рамках стратегической коммуникации используют персуазивную ценность интегрированной маркетинговой коммуникации» [Jachimowski 2016: 15].

Учитывая приведенный выше ход мыслей, следует признать, что М. Яхимовский выступает за признание понятийного сходства (в том числе аксиологического) стратегической коммуникации и пропаганды, однако в дальнейшей части статьи формулирует противоположные заявления, совершает персуазивное разграничение на губительную и предпочтительную политизацию средств массовой информации и утверждает: «В ситуации, когда для безопасности общества власть использует инструмент стратегической коммуникации, журналистская профессия является важной структурой общественного доверия, способствующей стратегическим действиям государства и нации как суверена» [Jachimowski 2016: 21-22], - чтобы в последних абзацах текста вернуться к исходному посылу: «Стратегическая коммуникация использует, как мы указывали ранее, многие инструменты. Журналистская профессия не является непосредственным инструментом этой коммуникации. Периодические медиа в демократическом государстве не могут рассматриваться как обычные инструменты политики» [Jachimowski 2016: 23].

Описывая историю интересующей нас проблемы, необходимо отметить, что в зависимости от принятого способа мышления в ее область следовало бы включить обширную рефлексию, посвященную пропаганде и маркетинговой коммуникации. Однако поскольку основная цель статьи - описание выбранных механизмов медиально опосредованной стратегической коммуникации, а также в связи с ограничением объема выбранного научного жанра сознательно отказываюсь от широкого рассуждения.

\section{Описание методики исследования}

Выбор аналитического материала. Как говорилось выше, одним из проявлений (или одной из плоскостей реализации) стратегической коммуникации является спонсируемая институциональным отправителем (органами власти, прежде всего правительством) деятельность средств массовой информации, заключающая- 
ся в распространении определенного содержания, важного для отправителя или получателя с точки зрения перспективы либо самого содержания (значимого для отправителя), либо возможности использования этого содержания (как важного для получателя) для выстраивания положительных отношений между отправителем сообщения и потенциальным адресатом. Отметим, что разграничить эти мотивы довольно трудно.

Предполагая, что отдельные действия диспонента медиа, являющиеся основой стратегической коммуникации, соответствуют ее плану, можно признать, что анализ одного из проявлений этого соответствия позволит сделать выводы о данной стратегической коммуникации. Объектом исследования в статье является информационный сервис первой программы польского общественного телевидения Wiadomości, вышедший в эфир 16 ноября 2018 г. Полагая, что общественные СМИ реализуют информационную политику диспонента медиа, так называемую политику власти, описание механизмов завоевания аудитории в анализируемом выпуске Wiadomości следует считать способом выявления ценностей, к которым обращается правительство Республики Польша в процессе создания нарративов, формирующих его имидж.

Аналитическая процедура. Механизмы завоевания аудитории реализуются в двух планах функционирования текста - в плане содержания и в плане выражения. В случае с выбранным объектом исследования, информационным сервисом Wiadomości, говоря о плане содержания, необходимо обратить внимание на выбор тем, обсуждаемых в анализируемой информационной программе, их характеристики и причины, по которым эти темы были затронуты. В то же время, говоря о плане выражения, следует иметь в виду использование приемов, направленных на принятие адресатом определенного нарратива о Польше (а именно об актуальной польской власти), прежде всего использование разных способов оценивания действительности, являющейся предметом речи.

Хотелось бы подчеркнуть, что оба плана - содержания и выражения - взаимопроникающие. Проявлением этого взаимопроникновения служат тематическое деление анализируемой программы, а также тесная взаимосвязь оценки с затронутыми темами.

Теоретический контекст исследования. Теоретический контекст исследования определяет цели анализа.

Во-первых, стоит отметить, что оценка рассматривается как персуазивная категория. В наших рассуждениях происходит отсылка к рефлексии на тему интенциональности сообщения, начало которой в польской науке положили Антоний Фурдала [Furdal 1977] и Валерий Писарек [Pisarek 1976]. Вслед за польскими лингвистами стоит признать, что оценка является не только показателем экспрессии адресанта, но и способом персуазивного воздействия. Такой способ мышления раскрывается во многих публикациях, например в статьях Элжбеты Ласковской и Дануты Кэмпы-Фигуры [Laskowska 2008; Kępa-Figura 2009].

Во-вторых, необходимо разграничивать понятия оценки и ценностей. Вслед за польской исследовательницей Ядвигой Пузыниной ценности будут рассматриваться как аксиологическая категория, которая относится к тому, 1) «в какой степени что-то является хорошим или является ли что-то хорошим», 2) «что считается хорошим», 3) «что хорошо в духовном смысле», 4) (филос.) «что хорошо или пло- 
хо» [Puzynina 1993: 16]. Как пишет Станислав Гайда, ценностями могут быть идеи, убеждения, идеалы, материальные предметы, считающиеся значимыми для общества и отдельной личности [Gajda 1997: 11].

Признавая, что ценности - это результат оценивания, вслед за Я.Пузыниной трактуем этот процесс как «психическое действие человека, заключающееся в утверждении о том, какие (в какой степени) ценности, положительные или отрицательные, присущи, по мнению оценивающего лица, данным характеристикам, поведению и - косвенно - предметам» [Puzynina 1992: 83].

В-третьих, желая обозначить нарративы, основанные на ценностях, к которым обращается адресант стратегической коммуникации, необходимо дать определение понятию нарратив. Нарратив трактуется как познавательная схема, «особая форма познавательной репрезентации действительности» [Trzebiński 2002: 14-16]. При этом нарратив является инструментом воздействия, поскольку эти схемы форма оценивающего упорядочивания мира (ср.: [Ке̨ра-Figura 2019]).

Анализ материала. Описывая механизмы, способствующие завоеванию аудитории в процессе стратегической коммуникации, стоит обратить внимание на структуру исследуемого выпуска Wiadomości от 16 ноября 2018 г. Она основывается на девяти темах, которые можно выделить из транслируемых сообщений:

(1) получение экономической награды Президента Республики Польша компанией «Ultratech» - производителем запчастей и компонентов для мировых компаний из промышленных секторов: авиационного, космической инженерии и энергетики;

(2) ситуация банка «Getin Bank» и внутренний контроль Комитета по финансовому надзору;

(3) открытие отделений полиции;

(4) результаты опроса, касающегося социальной поддержки партии «Право и справедливость» (далее - $\mathrm{PiS})$;

(5) иностранные вопросы (политические события в Великобритании; значение Польши для Германии и США; практика Европейского союза относительно судебной системы Польши и других государств - членов союза);

(6) поведение представителей польской политической оппозиции - соавтора репортажа TVN и Ежи Овсяка (организатора акции «Большой оркестр праздничной помощи»);

(7) Кубок мира по прыжкам на лыжах с трамплина;

(8) авария Рышарда Шурковского (знаменитого польского велогонщика);

(9) приглашение на фильм «Независимость».

Важно отметить, что анонс программы Wiadomości включает только три темы из перечисленных - (1), (6) и (7). Следует признать, что эти вопросы считаются важными из-за их прямой или косвенной выгоды в достижении целей стратегической коммуникации. Тема (1), анонсированная редактором и ведущей анализируемого выпуска Wiadomości Данутой Холецкой фразой Polski biznes wypływa na szerokie wody (Польский бизнес выпльвает на широкие воды), вводит положительную оценку работы властей. Интерпретационным ключом темы (6) является произнесенный Холецкой эквивалент предложения Nazistowskie pozdrowienie współautora reportażu TVN (Наиистское приветствие соавтора репортажа TVN), однозначно отрицательно характеризующий лагерь оппозиции. В свою очередь, последняя из выделенных тем - (7) Rusza Puchar Świata w skokach narciarskich 
(Стартует Кубок мира по прыжкам на льжах с трамплина) - призвана выполнять функцию объединения.

Не менее важно, что практически все темы, составляющие проанализированный выпуск Wiadomości, были отправной точкой для развития других, более общих вопросов. Продолжением темы (1) (получение фирмой «Ultratech» экономической награды Президента Республики Польша) стал репортерский материал, посвященный ситуации в польской экономике и гуманитарной помощи, предоставленной Польшей жертвам войны. Репортаж на тему ситуации банка «Getin Bank» и внутреннего контроля Комитета по финансовому надзору (2) развил высказывание о состоянии польского банковского дела и польской финансовой системы. Тему (3) - открытие отделений полиции - продолжило высказывание о состоянии полиции и безопасности граждан. Обсуждение результатов опроса, касающегося социальной поддержки PiS (4), дополнено высказыванием о политическом оппоненте PiS - «Гражданской коалиции». Такие зарубежные вопросы, как политические события в Великобритании и значение Польши для Германии и Соединенных Штатов (5), раскрываются через материал, посвященный практике Европейского союза в отношении судебной системы Польши и других государств - членов союза. Последняя тема социально-политического характера (6) построена в виде ряда высказываний о поведении представителей польской политической оппозиции соавтора репортажа TVN и Ежи Овсяка (организатора акции «Большой оркестр праздничной помощи»). В свою очередь, три завершающих выпуск тематических сообщения (Кубок мира по прыжкам на лыжах с трамплина; авария Шурковского; приглашение на фильм «Независимость», 7-9) можно рассматривать как целое, построенное вокруг мотива «важно для целевой аудитории Wiadomości», поскольку спорт в наши дни - это тема, формирующая чувство идентичности и общности значительной части поляков, а тема независимости особенно важна для избирателей PiS.

В выделенные тематические части были включены также характеристики, оценивающие диспонента медиа и мир противников. Вырастая из системных свойств языка, оценка является механизмом, определяющим свойства схем, используемых человеком в познании мира. Эти механизмы можно проиллюстрировать примерами, взятыми из темы (1) «Компания “Ultratech"» (замеченные проявления оценки будут выделены жирным шрифтом, а модальные слова, являющиеся выражением отношения говорящего к содержанию сообщения, - подчеркиванием).

Показывая процесс оценивания на примере темы (1), необходимо обратить внимание на частотность появления оценки:

(a) redaktor prowadząca Danuta Holecka:

- (o przedsiębiorcach zebranych na Kongresie 590; na pasku. - D. K.-F.): POLSCY PRZEDSIĘBIORCY ŁAPIĄ WIATR W ŻAGLE; ulepszaja swoje firmy; rozpędzają gospodarkę],

- Polski biznes wyplywa na szerokie wody.

ведущая Данута Холецка:

- (о предпринимателях, собравшихся на Конгрессе 590: текстом. - Д. К.-Ф.) ПОЛЬСКИЕ ПРЕДПРИНИМАТЕЛИ ЛОВЯТ ВЕТЕР В ПАРУСА; улучนают свои фирмь, разгоняют экономику,

- Польский бизнес выпльвает на широкие водь ${ }^{8}$.

${ }^{8}$ Букв. «выплыть на широкие воды», т.е. расширить границы деятельности. - Коммент. пер. 
(b) premier Mateusz Morawiecki:

- O sile polskiej gospodarki świadczy wspótpraca między małymi, średnimi, wielkimi [przedsiębiorstwami. - D. K.-F.] i państwem polskim.

премьер Матеуш Моравецки:

- О силе польской экономики свидетельствует сотрудничество между маленькими, средними, большими [предприятиями. - Д. К.-Ф.] и польским государством.

(c) reporter Waldemar Stankiewicz:

- Dziś spółka jest wiodącym producentem...

- Sukces zostat doceniony nagroda gospodarcza Prezydenta RP...

- Co zrobić, by trafić do grona najlepszych?..

- Rozwój i inwestycje nie tylko wzmacniają konkurencyjność polskich firm, ale i przekładaja się na korzyści dla gospodarki.

репортер Вальдемар Станкевич:

- Сегодня компания является ведущим производителем...

- Успех был отмечен экономической наградой Президента Польши...

- Что сделать, чтобы попасть в ряды лучших?..

- Развитие и инвестиции не только укрепляют конкурентоспособность польских фирм, но и становятся выгодными для экономики.

(d) minister Jarosław Gowin:

- W Polsce znakomicie rozwijają się te tradycyjne branże przemystu, ale przyszłość należy do przemystu 4.0, czyli do produktów innowacyjnych.

министр Ярослав Говин:

- В Польше превосходно развиваюотся эти традииионные отрасли промышленности, но будущее за индустрией 4.0, то есть за инновационными продуктами.

(e) reporter Waldemar Stankiewicz; w tle jego wypowiedzi materiał filmowy z wypowiadającym się premierem Morawieckim:

- O czym mówił też premier i przypominał o spetnionych obietnicach wobec przedsiębiorców. Konstytucja dla biznesu działa już od pół roku, a to szereg ulg i ułatwień dla biznesu.

корреспондент Вальдемар Станкевич; на фоне его выступления кадры с высказыванием премьер-министра Моравецкого:

- О чем говорил также премьер и напомнил о выполненных обещаниях предпринимателям. Конституциия для бизнеса работает уже полгода, а это иельй ряд льгот и возможностей для бизнеса.

(f) premier Mateusz Morawiecki; mimika zadowolenia:

- My rzeczywiście, Drodzy Państwo, uwolniliśmy potencjał polskiej gospodarki. Najszybszy wzrost gospodarczy w Unii Europejskiej w tym kolejnym kwartale, $w$ którym Eurostat podat. Jest się z czego cieszyć.

премьер-министр Матфей Моравецкий; мимика удовлетворения:

- Mь действительно [Drodzy Państwo] высвободили потеницал польской экономики.

Быстрый экономический рост в Евросоюзе в этом очередном квартале, который представил Евростат. Есть чему радоваться.

(g) reporter Waldemar Stankiewicz:

- W dobrej kondycji sa też polskie firmy. Największa polska firma ubezpieczeniowa PZU od stycznia do końca września wypracowała prawie 4 miliardy zysku netto.

корреспондент Вальдемар Станкевич:

- В хорошем состоянии также польские компании. Крупнейшая польская страховая компания PZU с января до кониа октября получила почти 4 миллиарда чистой прибыли. 
(h) prezes PZU SA:

- Przełamaliśmy tę magiczną granicę miliarda złotych za jeden kwartał. To faktycznie niebywale dobry wynik.

председатель правления PZU SA:

- Мы перешли эту магическую границу миллиарда злотых за квартал. Это действительно невероятно хороший результат.

(i) reporter Waldemar Stankiewicz:

- O wynikach polskich firm, cyberbezpieczeństwie, ale też o pomocy humanitarnej rozmawiano $w$ trakcie 2 dnia gospodarczego Kongresu. Na tym spotkaniu (w tle ujęcie ze spotkania) przypomniano, że Polska (w tle materiał filmowy przedstawiający uchodźców na pustyni. Na pierwszym planie na kocu leży dwoje dobrze wyglądających dzieci obok uśmiechającej się do nich kobiety) tylko w ubiegłym roku przeznaczyła 200 milionów złotych na pomoc ofiarom wojen.

репортер Вальдемар Станкевич:

- О результатах польских компаний, кибербезопасности, а также о гуманитарной помощи говорили в течение второго дня экономического конгресса. На этой встрече [на фоне кадры со встречи] напомнили, что Польша [на фоне кадры, изображающие беженцев в пустыне. На переднем плане на одеяле лежат двое хорошо выглядящих детей рядом с улыбающейся им женщиной] только в прошлом году выделила 200 миллионов злотых, чтобы помочв жертвам войн.

(j) Beata Kempa, pełnomocnik rządu ds. pomocy humanitarnej:

- To jest nie tylko dzięki decyzjom rządu co do wpłat do dużych organizacji, które niosa pomoc na całym świecie, ale przede wszystkim też niebywała aktywność polskich organizacji pozarzadowych.

Беата Кемпа, представитель правительства по гуманитарной помощи:

- Это не только благодаря решениям правительства относительно депозитов крупным организациям, которые несут помощь по всему миру, но прежде всего также небывалая активность польских неправительственных организаций.

В приведенных в качестве примеров высказываниях оценка проявляется благодаря использованию эмоционально окрашенных слов и словосочетаний (в том числе фразеологизмов - łapać wiatr w żagle, wypłynać na szerokie wody ${ }^{9}$ ). Эмоциональная оценка содержится либо в корнях смысловых слов (например, cyberbezpieczeństwo, siła, współpraca, wiodaccy, sukces ${ }^{10}$ ), либо в семантической коннотации (например, inwestycja, przemyst $4.0^{11}$ ). Оценка усиливается благодаря использованию модальных слов: naprawde, rzeczywiście, faktycznie ${ }^{12}$. В анализируемом выпуске Wiadomości оценка появляется не только в журналистских высказываниях, но и в цитатах. Последствие этого - оценка конкретных фрагментов действительности, сформулированная прямо или в виде пресуппозиций. Для реализуемой с помощью СМК стратегической коммуникации характерно, что приведенные в качестве примера высказывания журналистов и представителей власти вписываются в один нарратив о мире.

9 «Ловить ветер в паруса», букв. «выплыть на широкие воды», т. е. расширить границы деятельности.

10 «Кибербезопасность», «сила», «сотрудничество», «ведущий», «успех».

11 «Инвестиция», «индустрия 4.0».

12 Все перечисленные слова являются синонимами и используются для подтверждения истинности высказывания: «вправду», «на самом деле», «действительно». 
Механизмом, основанным на оценке, является противопоставление, заключающееся во вписывании отдельных элементов действительности в рамки поляризованных историй, в которых диспонент медиа и его мир оцениваются положительно, а оппоненты и их мир - отрицательно.

В сообщении (1) комментарий на тему компании «Ultratech» становится отправной точкой пропаганды успеха власти. Этот успех касается достижений в экономической и гуманитарной сферах. Партия власти репрезентуется представителями власти (министром науки и образования Ярославом Говиным, премьер-министром Матеушом Моравецким) и польских фирм (PZU и предпринимателей, которые встретились на «Конгрессе 590»). Эту сторону характеризируют высказывания журналистов, содержащие положительную оценку:

Pod Rzeszowem spotkali się przedsiębiorcy, którzy nie tylko wcią̇ ulepszaja swoje firmy, ale rozpędzaja gospodarkę; O wynikach polskich firm, cyberbezpieczeństwie, ale też o pomocy humanitarnej rozmawiano $w$ trakcie drugiego dnia gospodarczego Kongresu. Na tym spotkaniu przypomniano, że Polska (на фоне появляются кадры, изображающие беженцев в пустыне. На переднем плане на одеяле лежат двое хорошо выглядящих детей рядом с улыбающейся им женщиной) tylko w ubiegłym roku przeznaczyła 200 milionów złotych na pomoc ofiarom wojen ${ }^{13}$.

а также высказывания представителей власти (например, премьер: O sile polskiej gospodarki świadczy współpraca między małymi, średnimi, wielkimi i państwem polskim; My rzeczywiście, Drodzy Państwo, uwolniliśmy potencjał polskiej gospodarki ${ }^{14}$ ) и польских предпринимателей (председатель правления PZU SA: Przełamaliśmy tę magiczna granice miliarda złotych za jeden kwartał. To faktycznie niebywale dobry wynik ${ }^{15}$ ).

Выделение и характеристика противников СМИ появляются в теме (1) только в виде прагматических пресуппозиций. Это «те, которых не было на "Конгрессе 590”, те [ОНИ], которым не удалось раскрыть потенциал польской экономики» (ср., например, премьер: My rzeczywiście, Drodzy Państwo, uwolniliśmy potencjał polskiej gospodarki ${ }^{16}$ ). Важным контекстом, порождающим упомянутые пресуппозиции, было указание места проведения «Конгресса 590» под Жешувом, т.е. в Подкарпатье, являющемся резиденцией «Права и справедливости».

В части (2), инициированной материалом о ситуации с «Getin Bank» и внутренним контролем Комитета по финансовому надзору и раскрытой высказыванием на тему положения польского банковского дела и польской финансовой системы, положительно оценивается сторона власти, представленная Комитетом по финансовому надзору, Центральным антикоррупционным бюро, премьером Матеушом Моравецким, Комитетом по финансовой стабильности, Министерством финансов, Польским национальным банком (ср. высказывание Адама Глапиньского: Każda

13 «Под Жешувом встретились предприниматели, которые не только улучшают свои фирмы, но и разгоняют экономику; О результатах польских компаний, кибербезопасности, а также о гуманитарной помощи говорили в течение второго дня экономического конгресса. На этой встрече напомнили, что Польша только в прошлом году выделила 200 миллионов злотых, чтобы помочь жертвам войн».

14 «О силе польской экономики свидетельствует сотрудничество между маленькими, средними, большими [предприятиями] и польским государством; Мы действительно [Drodzy Państwo] высвободили потенциал польской экономики».

15 «Мы перешли эту магическую границу миллиарда злотых за квартал. Это действительно невероятно хороший результат».

16 «Мы действительно [Drodzy Państwo] высвободили потенциал польской экономики». 
sytuacje potrafimy uporządkować, uspokoić. I żaden klient Banku nie powinien się niepoko$i c^{17}$ ), Банковским гарантийным фондом ([polski system bankowy. - Д. К.-Ф.] jest jednym z najlepiej przygotowanych na ewentualny kryzys na tle innych europejskich banków. Wykazały to niedawne stres testy, czyli badania odporności banków ${ }^{18}$ ).

Отрицательно оцениваемых оппонентов СМИ и их мир демонстрируют обвиненный в коррупции бывший глава Комитета по финансовому надзору Марек Хшановский и банковская империя Лешека Чарнецкого (корреспондент: na tym tle blado wygląda imperium Leszka Czarneckiego, które od dtuższego czasu przeżywa poważne problemy $\left.{ }^{19}\right)$. Здесь честность и успех МЫ противопоставляются ИХ коррупции и кризису.

В свою очередь, сообщение об открытии полицейских участков (3) позволяет противопоставить власть представляющему противников нынешней власти бывшему руководству PO-PSL (коалиции «Гражданской платформы» и «Польской крестьянской партии». - Пер.). Открытие нынешней властью отделений полиции и улучшение условий труда полицейских считается успехом, инвестициями в безопасность. Закрытие постов прежней властью в сфере пресуппозиции оценивается как проявление нарушения безопасности поляков:

Nowe posterunki Policji, nowi funkcjonariusze, nowe śmigłowce i to nie tylko w Policji. To część inwestycji w bezpieczeństwo. Do 2020 roku rząd chce przeznaczyć na ten cel ponad 9 miliardów złotych. Dzięki tym środkom między innymi otwierane są, wcześniej zamykane przez rząd PO$P S L$ - posterunki ${ }^{20}$

Очень выразительно противопоставление власти и ее противников в (4) структурном элементе. Правящей партии здесь присваивается общественная поддержка (надпись PRAWO I SPRAWIEDLIWOŚĆ NA CZELE SONDAŻU ${ }^{21}$ ), а остальным партиям - «Современной» и «Гражданской платформе» - внутренние проблемы (KRYZYS W KOALICJI OBYWATELSKIEJ; Holecka: Nowoczesna likwiduje struktury na Podkarpaciu. Około 200 lokalnych działaczy złożyło rezygnację z członkostwa w partii Katarzyny Lubnauer ${ }^{22}$ ).

Следует подчеркнуть, что положительные сообщения на тему власти и отрицательные, касающиеся противников власти, подкрепляются видеоматериалами и фотографиями, а также жестикуляцией и мимикой (мимика принятия или непринятия).

17 «Мы можем наладить, утихомирить каждую ситуацию. И ни один клиент банка не должен беспокоиться».

18 «[польская банковская система] является одной из наиболее подготовленных к возможному кризису на фоне других европейских банков. Показали это недавние стресс-тесты, т. е. испытания устойчивости банков».

19 «На этом фоне бледно выглядит империя Лешека Чернецкого, которая уже давно испытывает серьезные проблемы».

20 «Новые полицейские участки, новые сотрудники, новые вертолеты, и это не только в полиции. Это часть инвестиций в безопасность. До 2020 г. правительство хочет выделить на эти цели около девяти миллиардов злотых. Благодаря этим средствам, в частности, открываются закрытые руководством PO-PSL отделения».

21 «ПРАВО И СПРАВЕДЛИВОСТЬ ВО ГЛАВЕ ОПРОСА».

22 «КРИЗИС В ГРАЖДАНСКОЙ КОАЛИЦИИ»; Холецка: «Современная власть ликвидирует структуры на Подкарпатье. Около 200 местных активистов отказались от членства в партии Катажины Лубнауэр». 
Результаты исследования. Проведенный анализ свидетельствует, что оценка в рамках медиально опосредованной стратегической коммуникации - часто и систематически используемый механизм, служащий завоеванию аудитории, т.е. завоеванию принятия продвигаемого отправителем мировосприятия и его имиджа. Исследование медиального материала с точки зрения появления в нем оценки показал, что миру диспонента Wiadomości, т.е. власти, приписываются положительные ценности. Почти все перечисленные выше темы связаны с одной из двух ценностей: «успех» и «патриотизм». Ссылаясь на эти ценности, отправитель передает нарратив о себе как о субъекте с патриотическими мотивами, оказывающимися успешными. Использование этого нарратива имеет, как было сказано ранее, персуазивные последствия.

Важно, что ценности «успех» и «патриотизм» были выбраны в соответствии с принципами стратегической коммуникации. Эти ценности важны для аудитории Wiadomości. Первая из них - ycnex - имеет характер надидеологический, общечеловеческий. Независимо от политических условий она создает положительный имидж стратегического отправителя. Вторая ценность - nатриотизм, - хотя и может показаться бесспорной в пределах данной национальной общности, является отличительной особенностью определенного мировоззрения и даже политического выбора. Основа нынешнего лагеря власти в Польше - избиратели «Права и справедливости». Это правый электорат ${ }^{23}$, главными для которого являются национальные ценности. Как пишут Ежи Бартминский и Войчех Хлебда, ссылающиеся на рапорт Фонда им. Стефана Батора от декабря 2016 г., «около двух третей польского общества к концу 2016 года проявляют растущую неприязнь к внешнему миру и явные изоляционистские тенденции, называющиеся “нативизмом” - отношением, характеризующимся дистанцией или неприятием иностранцев, критическим отношением к этническому и религиозному разнообразию и определением собственного народа прежде всего в этнических категориях, а не гражданских» [Bartmiński, Chlebda 2018: 208] ${ }^{24}$.

Завершая наше исследование, хотелось бы обратить внимание на отношения, в которые вступает StratCom с понятиями $P R$ и nропаганда, и тем самым попытаться ответить на вопрос, нельзя ли явления, называемые StratCom, использовать в PR или пропаганде. Прежде всего, перечисленные понятия имеют две объединяющие особенности. Во-первых, они возникли с целью объективации субъективных ценностей отправителя. Думается, что наиболее важным мотивом было желание создать нейтральную номинацию явления, которое может оцениваться негативно. Во-вторых, эти понятия возникли с идеологическим намерением формирования взглядов пользователей языка относительно этических и эпистемологических эф-

${ }^{23} \mathrm{~B}$ настоящее время почти две трети электората PiS составляют избиратели, приравнивающиеся к правому политическому сектору (ср.: [Komunikat z badań CBOS Nr 130/2017: 11]).

24 Эту точку зрения подтверждает также характеристика взглядов сторонников PiS, содержащаяся в сообщении CBOS от июня 2015 г.: «Сторонники PiS отличаются большим скептицизмом в отношении к процессу углубления европейской интеграции. Около половины из них (53\%) выступают за сохранение за Польшей далекоидущей независимости в ЕС. За укрепление сотрудничества в организации выступает каждый четвертый избиратель PiS (26\%). За последние четыре года в электорате PiS, как и во всем обществе, увеличилась дистанция относительно постулатов о развитии европейской интеграции. Подавляющее большинство сторонников партии (77\%) выступают против введения в Польше евро» [Komunikat z badań CBOS Nr 85/2015: 10-11]. 
фектов при сравнении склоняющего воздействия (соответствующего целям управляющего коммуникацией субъекта) с информированием.

Можно считать, что современная стратегическая коммуникация функционирует наподобие понятия public relations: в нее включена перспектива отправителя, вовлеченного в действия, названные этими наименованиями. По сути нейтральные и даже положительные StratCom и $P R$ могут использоваться для определения действий, оцениваемых внешними субъектами как отрицательные. Кроме того, характеризуя отношения между понятиями стратегическая коммуникация и связи с общественностью, необходимо обратить внимание на заключающееся в них доминирование положительного мировосприятия. Отметим, что позитивное ви́дение мира является основой одной из разновидностей пропаганды - пропаганды успеха.

Желая упорядочить приведенные выше термины в плане утрачивания внесенной в них изначально установки на беспристрастность, следует руководствоваться хронологией их возникновения. Слово пропаганда очень редко используется в нейтральных контекстах, а $P R$ все реже рассматривается как нейтральное определение. Оба понятия вошли в польский язык и обрели в нем негативный оттенок. StratCom и стратегическая коммуникация не являются широко используемыми терминами. Эти определения встречаются в профессиональных текстах - во внутренней институциональной коммуникации и в научных рассуждениях. Более широкое использование описываемой в исследовании категории, на наш взгляд, приведет к стилистическому окрашиванию этого понятия.

Перевод А. В. Подвязкиной

\section{Литература/References}

Bartmiński, J., Chlebda W. (2018). Obrazy Europy w języku polskim w tekstach polskich dyskursów publicznych. In W W. Chlebda (ed.), Leksykon aksjologiczny Stowian i ich sąsiadów. T. 2. Europa (pp. 169-216). Lublin; Opole: Wydawnictwo Uniwersytetu Marii Curie-Skłodowskiej.

Furdal, A. (1977). Językoznawstwo otwarte. Opole: Ossolineum.

Gajda, J. (1997). Wartości w życiu człowieka. Prawda - miłość - samotność. Lublin: Wydawnictwo Uniwersytetu Marii Curie-Skłodowskiej.

Information Operations (2006). Joint Publication 3-13. Retrieved from http://www.acqnotes.com/Attachments/Joint\%20Publication\%203-13\%20Information\%20Operations\%2013\%20Feb\%2006.pdf.

Jachimowski, M. (2016). Komunikacja strategiczna a dziennikarstwo. Rocznik Prasoznawczy, 10, 11-27.

Kacała, T. (2010). Propaganda marketingowa, public relations czy public affairs jako element komunikacji strategicznej? Zeszyty Naukowe AON, 4 (81), pp. 350-362.

Kacała, T. (2012). Komunikacja strategiczna. Przegląd Morski, 3, pp. 17-27.

Kacała, T. (2015). Podstawowe założenia koncepcji komunikacji strategicznej w Siłach Zbrojnych RP. Bellona, 2, pp. 145-159.

Kępa-Figura, D. (2009). "Mówię, więc jestem” — problem intencjonalności w programach informacyjnych. In W M. Filiciak, G. Ptaszek (ed.), Komunikowanie się w mediach elektronicznych - język, semiotyka, edukacja (pp. 146-166). Warszawa: Wyd. Akademickie i Profesjonalne.

Kępa-Figura, D. (2019). Obcy (czyli wróg) - narracja o wrogu jako narzędzie oddziaływania nakłaniającego w dyskursie publicznym. In M. Czampka-Wewióra, A. Kalisz, M. Ślawska (ed.), Komunikacja ponad granicami. Prace dedykowane Profesor Małgorzacie Kicie (pp. 229-244). Katowice: Wydawnictwo Uniwersytetu Śląskiego, Wydawnictwo Gnome.

Komunikat z badań CBOS Nr 130/2017 - Elektoraty PO i PiS w ostatnich dwunastu latach. Retrieved from https://www.cbos.pl/SPISKOM.POL/2017/K_130_17.PDF.

Komunikat z badań CBOS Warszawa, czerwiec 2015, NR 85/2015 - Charakterystyka poglądów potencjalnych elektoratów partyjnych. Retrieved from https://www.cbos.pl/SPISKOM.POL/2015/K_085_15.PDF. 
Laskowska, E. (2008). Wartościowanie jako środek perswazji. In E.Laskowska, M. Jaracz, I. Benenowska (Ed.), Język, społeczeństwo, wartości (pp. 219-226). Bydgoszcz: Bydgoskie Towarzystwo Naukowe.

Łukasiuk, M. (2014). PR NGOsów. Komunikacja strategiczna organizacji pozarządowych. Warszawa: Wydawnictwo Naukowe Sub Lupa.

Modrzejewski, Z. (2014). Operacje informacyjne i psychologiczne jako zdolności komunikacji strategicznej. Bellona, 3 (678), pp. 162-174.

Nowicka, J., Załoga, W., Ciekanowski, Z. (2018). Komunikacja strategiczna w naukach o zarządzaniu i jakości oraz w naukach o bezpieczeństwie. Zeszyty Naukowe Wyższej Szkoły Zarządzania Ochroną Pracy w Katowicach, 1 (14), pp. 193-202.

Pisarek, W. (1976). Język służy propagandzie. Kraków: Ośrodek Badań Prasoznawczych RSW "Prasa-Książka-Ruch".

Puzynina, J. (1992). Język wartości. Warszawa: Wydawnictwo Naukowe PWN.

Puzynina, J. (1993). O znaczeniu wartości. Nazwy wartości. In J. Bartmiński, M. Mazurkiewicz-Brzozowska (ed.), Studia leksykalno-semantyczne (pp. 9-21). Lublin: Wydawnictwo UMCS.

Regulamin działań wojsk lądowych (2008). Dowództwo Wojsk Lądowych wewn. 115/2008. Warszawa. Retrieved from https://insib.uph.edu.pl/images/Legia_Akademicka/Regulamin_dzialan_wojsk_ladowych.pdf.

Szymańska, A. (2014). Znaczenie mediów w strategicznej komunikacji zewnętrznej państwa - szkic teoretyczny. Zeszyty Prasoznawcze, 2 (218), 273-292.

Trzebiński, J. (2002). Wstęp. In J.Trzebiński (ed.), Narracja jako sposób rozumienia świata (pp. 13-16). Gdańsk: GWP.

Zgryziewicz, R. (2018). Komunikacja Strategiczna elementem kształtowania środowiska informacyjnego. Bezpieczeństwo a wyzwania współczesności. Retrieved from https://www.academia.edu/37973006/ Komunikacja_Strategiczna_elementem_kształtowania_środowiska_informacyjnego_Bezpieczeństwo_a_wyzwania_współczesności_Uniwersytet_Szczeciński_2018_ISBN_978-83-7972-2242_s._191-206.

Статья поступила в редакцию 10 апреля 2019 г; рекомендована в печать 16 июля 2019 г.

Контактная информация:

Кэмпа-Фигура Данута - д-р филол. наук, проф.; dkepa@op.pl

\section{Audience acquisition in the mediated strategic communication (on the example of the Polish news service "Wiadomości")}

\section{Kepa-Figura}

Maria Curie-Sklodowska University in Lublin, 3, pl. Litewski, Lublin, 20-080, Poland

For citation: Kępa-Figura D. (2019). Audience acquisition in the mediated strategic communication (on the example of the Polish news service "Wiadomości"). Media Linguistics, 6 (4), 496-511. https://doi.org/10.21638/spbu22.2019.406 (In Russian)

The article analyzes one exemplary edition of "Wiadomości" - a news service of Polish public television. The program is framed as a medium implementing the information policy of their administrator, i.e. the policy of power. The focus was placed on evaluation as the most expressive linguistic mechanism of strategic communication. The analysis of evaluation, defined as a mechanism of audience acquisition, allowed the author to identify the values referred to by the government of the Republic of Poland in the process of creating the narratives ultimately shaping its image. The values of 'success' and 'patriotism' have become the basis for popularizing the narrative of the government as the entity with patriotic motivations, which prove successful. The mechanism of audience acquisition is implemented into two planes of text func- 
tioning which are the content plane and the expression plane. In the case of selected object of study, speaking about the content plane, it is necessary to pay attention to the choice of topics covered in the analyzed information program, their characteristics and the reasons for which these topics were raised. At the same time, speaking of the expression plane, it is necessary to discuss the use of techniques that contribute to the acceptance of a certain narrative about Poland (namely the Polish government) and the use of different ways of evaluating the reality that is the subject of the speech. In addition, the author of this article draws attention to the relationship between the concepts of strategic communication, public relations and propaganda. Keywords: strategic communication, valuation, propaganda, $\mathrm{PR}$, narrative.

Author's information:

Danuta Kępa-Figura - Dr. Sci. in Philology, Professor; dkepa@op.pl 